\title{
Knowledge Management in Improving the Competitiveness of Chinese Advanced Manufacture Industry
}

\author{
Haiyan $\mathrm{ZHOU}^{1,2^{*}}$ \\ ${ }^{1}$ China Center for Economic Research, East China Normal University, Shanghai 200062, China \\ ${ }^{2}$ General Manager Office, Zhejiang Huaxing Feather Manufacture Co., Ltd., Hangzhou 311305, China \\ *Corresponding author. Email:yanjiulilun8@126.com; zhouhaiyansh@hotmail.com
}

\begin{abstract}
The advanced manufacture industry is the support and foundation of the economic and social development. Its transfer and quality upgrade are the important content of the structural reform, which helps improve the supply, enlarge the demand and promote the products and industry to march forward the middle-to-high end. Under the background of the deep adjustment of the global manufacture industry structure and the arrival of the new scientific and technical revolution, how to upgrade our advanced manufacture industry, and construct strong manufacture country and quality country is the significant issue requiring answer. In the knowledge economy era, the essence of the advanced manufacture industry competitiveness is the knowledge and the resource competitive power which has all the properties of the knowledge; knowledge is the most strategic core resource for the industry in the knowledge economy and data era; knowledge and knowledge management is the final home to return to and the single recourse for the industry competitiveness. Therefore, the strengthening of the knowledge management is urgent for upgrading our competitiveness in the advanced manufacture industry.
\end{abstract}

Keywords: advanced manufacture industry; knowledge management; competitiveness; innovation; Made in China

\section{INTRODUCTION}

At present, the new scientific and technical revolution and industry revolution has been bred and risen all over the world, which promotes the deep revolution in the production method and development pattern of the manufacture industry. The manufacture industry has again become the highlands of the global economic competition. The fifth plenary session of the eighteenth central committee clearly put forward to accelerate the construction of the strong manufacture country and the implementation of 2025 Made in China. The advanced manufacture industry is the core and spine of the manufacture industry, and the top priority for the construction of the strong manufacture country. It is necessary to follow the new trend of the development of the global manufacture industry, clearly know the development direction and key task, accelerate the development of advanced manufacture industry, and create new advantage for Made in China to provide strong support for the economy to maintain the middle- to-high speed and to march forward to the middle-to-high level. The advanced manufacture industry is in the high end of the manufacture industry value chain and the core link of the industry chain, and is the new strategic industry which determines the comprehensive competitiveness of the whole industry chain. In the area of the high end equipment manufacturing, China not only made a series important breakthrough in the areas such as the aviation, big airplanes, high speed railway, numerical control machine tools, new energy automobile, and etc., but also grew in the international portion in the high value added industries. In the area of the front manufacturing, Chinese enterprises break the foreign monopoly. The $5 \mathrm{G}$ application, super computer, unmanned aircraft, a group of new industry clusters are arising. At present, only by grasping the opportunity brought by the industry change to improve the quality, could our country be able to achieve the leap development in respect of the variety, quality and brand of the manufacture industry, improve the value and international reputation of Made in China 
and lay solid foundation for the construction of the strong manufacture country.

\section{THE KNOWLEDGE MANAGEMENT IS VERY IMPORTING IN THE DEVELOPMENT OF THE ADVANCED MANUFACTURE INDUSTRY}

In the past 40 years, there was huge change in Chinese advanced manufacture industry. Various manufacture equipment has developed rapidly in China, and make our country become the large country in the world advanced manufacture industry ${ }^{[1]}$. Although at present there is insufficient competition in many core technologies for Chinese advanced manufacture industry, it is undeniable that the gap between Chinese advanced manufacture industry and the world strong manufacture equipment countries is being shortened. The advanced manufacture industry in the middle-to-low end has been in the front of the world, while the high end equipment manufacture industry market has also spread in China. The Chinese advanced manufacture industry is now arising in the high end market.

The strategy of "exchange the technology by market" implemented since 1980s over emphasized the introduction of foreign technology while ignoring the absorption, digestion and re-creation, the result of which is that it is difficult to master the initiative in the product research and development. The core technology and equipment which could be leading in future is insufficient. This results in more difficulties in realizing the target to occupy the future advanced manufacture industry market by the technological competition advantage ${ }^{[2]}$. We could only expand the industry to change for the reduction of the manufacturing cost. Our advanced manufacture industry is featured with the characteristics of strong processing ability, weak innovation ability, large but not strong. The main reason is the serious deficiencies in the independent innovation ability. The weak innovation ability directly restricts the transfer of the advanced manufacture industry and the improvement of the competitiveness. The competitive advantage of our advanced manufacture industry mainly comes from the market occupancy and the cheap labor. However, the resources such as the market, labor, equipment and raw resources are easily to be taken away and imitated by the competitors, and are difficult to be the lasting competitive advantage in the industry; and are more difficult to improve the competitiveness, which is not helpful for the sustainable development of the advanced manufacture industry. Only by strengthening the knowledge management to cultivate the new industry advantage, could the manufacturing enterprises have the independent intellectual property and improve the independent innovation ability, and could the advantage of our advanced manufacture industry competitiveness be maintained.
The advanced manufacture industry is the technology intensive industry. The dependence on the technology and intellectual element by the product manufacturing process, live labor and the material labor process is much higher than other industries. The core key technology is the foundation for the sustainable development of the advanced manufacture industry. The key to master the technological resources such as the processing technology, production process and etc. is to have the independent research and development, design and manufacturing ability, in other words, the supply guarantee ability of the technological resources to support the competiveness. In recent years, our advanced manufacture industry has developed rapidly and the international competitiveness of the industry has been obviously improved. However, overall, there are still problems such as the low development quality, excessive low end productivity, the insufficient productivity of the advanced manufacture industry, the over dependence on foreign enterprises by the key and support industry, especially that the core and key technology of many exported products with international competitiveness still depend on foreign introduction. The industry common technologies are the necessary requirement for the advanced manufacture industry to achieve the successful transfer. Whether to have the market and the research and development resources, as well as the industry technology foundation is the key for China to transfer from the country with the great processing ability to the one with the strong innovation ability. However, after China reformed the scientific and technological system, all of the original industry research institutions were transferred to be enterprises. There is insufficient research on the industry common technologies, which results that our advanced manufacture industry is weak in the industry common technology research and the forward-looking research; and there are serious market failures and organization failures in the support and guarantee of the industry common technologies. There are serious insufficiencies in the supply of the core key technologies and the industry common technologies for our advanced manufacture industry. It is necessary to strengthen the knowledge management to promote the technological innovation and improve the industry competitiveness. One of the important components of the knowledge management system is the supportive resources. There are education resources, cultural resources, hard facility resources, and also the scare technological resources for the advanced manufacture industry. The strengthening of knowledge management is the inevitable choice to solve the insufficient technological resources for the competitiveness of the advanced manufacture industry.

The political production, study, research and use synergy innovation is the new organization innovation pattern in the new innovation ecology system environment. It refers to define the position of the 
enterprises as the main innovation body, and base on the scientific and research institutions and the scientific research and development in the high colleges to satisfy the demand of target users with the policy guide and incentive. In the synergy innovation model of the public research and development center, the university scientific park and the laboratory, the political production, study, research and use produce certain effect in respect of the technological consulting and transfer, entrustment development, etc., but there is no obvious effect on improving the independent research and development capacity of the manufacturing enterprises, as well as increasing the profit. At present, our advanced manufacture industry has relatively low independent research and development capacity. In some high colleges, the setup of the subject system and the curriculum is not scientific; the infrastructure and service facilities are not perfect; and the teaching team and science and research capacity is not strong. As such, the synergy effect has played limited role. A few colleges are still in the stage of cultivating talents by the combination of production, study and research. The synergy innovation should be extended and deepened. At the same time, some colleges, research institutions and the advanced manufacturing enterprises "fight independently". The research, development and application are separated from each other, resulting in that the transfer rate of our scientific and technological achievements remains at a very low level. There is no specialized division and coordination, no effectively operated common industry system and no improved technological innovation system. As such, no synergy effect of political production, study, research and use has been produced, which causes the low integration and use rate in the scientific and technological resources in the advanced manufacture industry. Building the research and development alliance, strengthening the knowledge service software construction and cultivating the comprehensive talents required by the knowledge competition are the important contents of the supporting activities in the knowledge management system. The strengthening of the knowledge management is helpful for the synergy innovation of the political production, study, research and use in the advanced manufacture industry.

\section{THE PROBLEMS IN FROM OF OUR ADVANCED MANUFACTURE INDUSTRY IN IMPLEMENTING THE KNOWLEDGE MANAGEMENT}

Under the trend of the integrated development of the internet and manufacture industry, some advanced manufacturing enterprises still do not realize the integrated development relationship between the internet and the manufacture industry. There is even some wrong understanding. In order to adapt to the internet thinking and develop the platform model, the enterprises over pursue the speed of the cooperation with the internet platform during the transfer, and ignore the quality in accumulating the competitive advantage by the political production, study, research and use knowledge alliance platform. Some enterprises equal the internetwork with the informationization. They only emphasize the informationization of the internal management to improve the short term part efficiency by investing the hard equipment such as the robot, sensor, etc., and ignore the internetwork cooperatively shared by the software system of the political production, study, research and use to improve the overall long term efficiency. Some enterprises consider that the internet is only another channel, and the marketing tool. They only pay attention to the commercial model innovation combined with the internet big data, while ignoring the essence of the knowledge innovation. In fact, the joining of the internet and the information big data provides the opportunity to build the transparent and fair advanced manufacturing enterprises on basis of the knowledge life cycle, which will better promote the knowledge management to help the competitive strategic transfer of the advanced manufacture industry. However, in reality, it is easy to mix the basic and the end. The enterprises only use the internet or the data technology to spread and share knowledge, but ignore the knowledge creation which is deeply rooted in the reality.

The competitiveness of the advanced manufacture industry depends on the core technology as well as the personnel who master and apply such core technology ${ }^{[3]}$. Most of the core technology is implicit knowledge and only be grasped by a few high level technicians. Such implicit knowledge is originated from the long term accumulation and direct experience. It is informal and non-code in form. It is difficult to regulate and explain, and even more difficult to express, spread and share. Because of the self-value consideration and the competition environment, the high level technicians who have certain valuable implicit knowledge are not willing to share such knowledge most of the time. The advanced manufacture industry has a large demand for talents. In the advanced manufacture industry, the core technology is in the hand of a few persons, and the high technological talents are deeply insufficient, which causes that it is difficult to manifest and spread the implicit knowledge.

The essence of the knowledge management is the process of the knowledge evaluation. The implementation of the knowledge management is the process to identify, obtain, develop, share, apply and store the knowledge according to the knowledge target, and then evaluate the knowledge and feedback the target. The reasonable knowledge evaluation is helpful for optimizing the knowledge target and achieving the effective knowledge management. Although the academia has made progress in the evaluation standards, index and method of knowledge management, and established the primary knowledge management 
evaluation system, different industries or enterprises have different methods to process the data and knowledge. As such, it is necessary to build the evaluation system with the industry characteristics. Because the knowledge management evaluation system in the advanced manufacture industry has not been built, it seems difficult to evaluate in quantity the profit from the knowledge management. First, as the emphasis of the evaluation, the implicit knowledge is stored in the brain of the personnel. The implicit knowledge is informal, and difficult to regulate. There are no universal standards. As such, it is difficult to measure the implicit knowledge, and even more difficult to evaluate in quantity the effect of the knowledge management. Second, the profit cycle of the knowledge management is long. Whether the knowledge value could be fully shown depends on the surrounding environment. The long profit cycle and environmental uncertainties add more difficulties for the long effect evaluation of the knowledge management. Because of the fierce and cruel market competition, no enterprises are willing to treat the market as the laboratory. Therefore, they do not have much enthusiasm to implement the knowledge management.

The cost theory considers that the industry competitiveness comes from that the same or even better products are produced with lower cost under the same conditions. The synergy symbiotic effect should influence the cost of the advanced manufacture industry in resource integration, and research and develop and share the common technologies. In recent years, the number of the advanced manufacture industry has increased rapidly. The rapid increase brings a lot of work to the knowledge management in the advanced manufacture industry, and causes high maintenance and operation cost. The informationization is the necessary condition of the knowledge management. The implementation of the knowledge management needs high level equipment or advanced system. However, the synergy symbiotic effect of political production, study, research and use has not been produced. There is still a long way to establish the environment with complete knowledge network, resource integration and the information sharing. Due to the uncertainty, long cycle and high input of the common technologies research and development in the advanced manufacture industry, the enterprises need to more depend on the synergy innovation of the political production, study, research and use. However, at present, some high colleges, enterprises and scientific research institutions make independent research and development on the common technologies, without smooth communication and the sense of knowledge alliance platform. As such, it is difficult to realize the synergic knowledge management, and they also face high operation cost and risk.

\section{THE COUNTERMEASURES TO UPGRADE OUR COMPETITIVENESS IN THE ADVANCED MANUFACTURE INDUSTRY BY WAY OF KNOWLEDGE MANAGEMENT}

At present, with the double effect of the knowledge economy and the innovation ecology system, for our advanced manufacture industry at the transfer stage with rapid development, it is necessary to put the knowledge management as the core strategic position in order to improve the competitiveness and achieve the transfer and upgrade.

In the internet ear, there are rich resources and broad knowledge. Under the big data background, the improvement of the competitiveness in the advanced manufacture industry is closely linked with the internet and the knowledge management. The advanced manufacture industry may obtain the advanced knowledge and technology by internet, share the key common knowledge and technology, and have effective resource integration. However, the knowledge management is unique and abstract $^{[4]}$. The modern information system could not replace the face to face meeting, establish the sharing "field" environment required by the knowledge creation, or effective promote the knowledge creation. People are the main body for the knowledge creation. The knowledge management is the information system management based on people, including the information management and the human resource management. The knowledge management based on people is to depend on modern information technology to comprehensively consider the unique, attaching and value added feature of the human resources, and effectively integrate the knowledge, information, technology and experience to promote the sharing of the knowledge resource and the management of the knowledge creation. Therefore, it is necessary to correctly realize the integrated development relationship between the internet and the advanced manufacture industry; avoid the potential risk brought by the integration and transfer of the advanced manufacture industry and the internet, such as the competition risk with the same nature, system friction risk and the data security risk. The enterprises should have the notion to equally and fairly treat the software and hardware, and pay attention to both the equipment and the system. When using the data and imitation technology, the enterprises should also emphasize the knowledge management based on people.

It is necessary to improve the driving force mechanism, emphasize the implicit knowledge and carry forward the craftsman spirit. We should actively cultivate large groups of modern craftsmen with knowledge, capacity, innovation sense and the sharing notion, and provide the scientific and technological support and 
guarantee for the core technology innovation and common technology sharing. For a long time, China is short of the craftsman spirit, while the strong manufacturing countries have, such as Germany, Japan, USA, etc. The distance with the craftsman spirit is the transfer from OK to perfect, from product to brand; and from manufacturing to "made by intellect". As such, the advanced manufacture industry should focus on improving quality the core competitiveness, guiding the enterprises to form their own comparative advantage, carrying forward the craftsman spirit, manufacturing the elaborate works, strengthening the brand building and cultivating more big country craftsman to improve the international competitiveness of our advanced manufacture industry to a larger degree. It is necessary to build the implicit knowledge communication and stimulus mechanism, make full use of the market and create the environment and conditions favorable for the craftsman spirit. Stimulating the implicit knowledge hidden in people's brain and achieving the targeted knowledge management depends on the effectiveness of the stimulus mechanism. Therefore, it is necessary to build the stimulus mechanism to encourage the employees to share their knowledge and manifest the implicit knowledge. In addition, we may also use the face to face method to share knowledge. For example, we may regularly organize the employees to discuss the new problems in the production and share the working experience. All people share and all people benefit. This will effectively mobilize the enthusiasm, encourage the craftsman spirit, and cultivate more modern craftsmen.

It is necessary to build the sharing knowledge base to provide the sharing platform for the explicit knowledge, achieve the combined and platform management for the intellect property right, build the knowledge alliance system with many innovation body participating and the synergy of many components, and further improve the knowledge management system of the political production, study, research and use. After the knowledge and skills in the form of words, graph, code and etc. is input into the knowledge repository, when the employees face the same problem or similar situation, they may directly use the knowledge and obtain the solution. We should build the intellect property right system with the combined body of the political production, study, research and use, and gradually lock the high end of the industry technological chain, such as the product research and development, key technology and brand operation. For example, in the product research and development stage, the advanced manufacture industry will need many computer resources. It is difficult for the enterprises to depend on their single research and development team, and the success is slim. Under the "internet +" background, the competitiveness transfer and upgrade in the advanced manufacture industry should depend on the advanced information technology, strengthen the construction of the information technology infrastructure, and effectively conduct the knowledge management. By the integration of the internet, the new information technology and the development of the advanced manufacture industry, the enterprises could learn from foreign enterprises to build the internal and external knowledge network system, and code the explicit knowledge in these systems according to category. By obtaining the effective knowledge through the knowledge management system, the enterprises may reduce the knowledge management cost, share the knowledge operation risk, accelerate the speed to gain knowledge, and achieve the effect of the knowledge creation.

\section{CONCLUSION}

The manufacture industry is the foundation of the country, the tool to the country rejuvenation, and the base for a strong country. The advanced manufacture industry is the core and support of manufacture industry; the important symbol of the industrialization development; and the basic and strategic industry which provides the technology and equipment for the national economy and the national defense construction. Since the foundation of the new China, especially the reform and opening, our advanced manufacture industry has made the impressive achievements, and has become the real large country with advanced manufacture industry. During the development of the advanced manufacture industry, the competition among enterprises has been fiercer and fiercer. The demand of the enterprises for knowledge is gradually complicated and diversifying. Only by emphasizing the knowledge innovation, could our advanced manufacture industry effectively use the knowledge in practice, and really improve the competitiveness.

\section{AUTHORS' CONTRIBUTIONS}

Haiyan ZHOU performed the policy analyses and wrote the manuscript.

\section{ACKNOWLEDGMENTS}

This work was supported by the Major Program of the National Social Science Foundation of China [grant number 20\&ZD124], the National Social Science Foundation of China [grant numbers 21CJY024, 20BJL040 , 19BJL108 , 19BJL185], the National Natural Science Foundation of China [grant numbers71773115, 72174180, 72074195, 71973129, 72072162], the Philosophyand Social Science Program of Zhejiang [grant number 22NDQN290YB , 22QNYC13ZD, 21NDYD097Z], the Humanity and Social Science Foundation of Ministry of Education of China [grant numbers 21YJA790043, , 21YJA630037, 19YJA790107 , 19YJA630092 ， 18YJA790088 , 21YJCZH213]. 


\section{REFERENCES}

[1] Abrami, R. M., Kirby, W. C. and McFarlan, F.W.,"Why China can't innovate", Harvard Business Review, 2014, (3), pp107-111.

[2] Hu F, Xi X, Zhang Y. "Influencing mechanism of reverse knowledge spillover on investment enterprises' technological progress:An empirical examination of Chinese firms",Technological forecasting \& social change, (2021) 169: 120797.

[3] Casella, B., "Looking through conduit FDI in search of ultimate investors - a probabilistic approach", Transnational Corporations, 2019,26(1),pp109-146.

[4] Stüer C, Hüsig S, Biala S.,"Integrating art as a transboundary element in a radical innovation framework",R\&D Management, 2010, 40(1), pp1018. 